\title{
First Record of Oxynoemacheilus angorae (Steindachner, 1897) from Perşembe Plateau Meandering Streams in the Ordu-Turkey
}

\author{
Serdar YEDIER ${ }^{1 *}$, Derya BOSTANCI ${ }^{2}$, Nazmi POLAT $^{3}$
}

\begin{abstract}
In the current study, for the first time, Oxynoemacheilus angorae samples were caught from Perşembe Plateau Meandering Streams in the Ordu-Turkey (Middle Black Sea Region). In the field studies, fifteen O. angorae individuals were sampled using electrofishing gear. After the captured samples were photographed, they were placed in fish transfer containers and transferred to the laboratory. Some metric numbers and meristic characteristics of the samples brought to the laboratory were recorded. The mean value of body weight of fish samples was determined as $2.39 \pm 0.576 \mathrm{~g}$. The mean values of standard length, fork length and total length of the samples were determined as $5.48 \pm 0.49 \mathrm{~cm}, 6.23 \pm 0.54 \mathrm{~cm}$ and $6.56 \pm 0.59 \mathrm{~cm}$, respectively. The result of this study, new fish species was added to freshwater fish fauna of Ordu and also provided a new data for the distribution areas $O$. angorae in Turkey.
\end{abstract}

Keywords: Oxynoemacheilus angorae, Perşembe Plateau Meandering Streams, freshwater fish fauna, Ordu-Turkey.

\section{Oxynoemacheilus angorae (Steindachner, 1897) Türünün Perşembe Yaylası Menderesleri Ordu-Türkiye'den İlk Kaydı}

\section{$\ddot{\mathbf{O} z}$}

$\mathrm{Bu}$ çalışmada, Oxynoemacheilus angorae türü Perşembe Yaylası Menderesleri Ordu-Türkiye (Orta Karadeniz Bölgesi)'den ilk kez kaydedilmiştir. Arazi çalışmalarında, on beş adet O. angorae bireyi elektroşoker yardımıyla yakalanmıştır. Yakalanan örnekler fotoğraflandıktan sonra balık transfer kaplarına konularak laboratuvara getirilmiştir. Laboratuvara getirilen örneklerin bazı metrik sayıları ve meristik karakterleri ölçülmüştür. Balık örneklerin ortalama vücut ağırlığ $2,39 \pm 0,57 \mathrm{~g}$ olarak belirlenmiştir. O. angorae'nin ortalama standart boy, çatal boy ve total boy uzunlukları sirasıyla $5,48 \pm 0,49 \mathrm{~cm}, 6,23 \pm 0,54 \mathrm{~cm}$ ve $6,56 \pm 0,59 \mathrm{~cm}$ olarak belirlenmiştir. Bu çalışmayla Ordu ilinin tatlı su balık faunasına yeni bir tür eklenmiş ve $O$. angorae türünün Türkiye'deki yayılış alanı içinde yeni bir veri sağlanmıştır.

Anahtar Kelimeler: Oxynoemacheilus angorae, Perşembe Yaylası Menderesleri, tatlı su balık faunası, Ordu-Türkiye.

\footnotetext{
${ }^{1}$ Ordu University, Faculty of Arts and Sciences, 52200 Ordu-Turkey, serdar7er@gmail.com

${ }^{2}$ Ordu University, Faculty of Arts and Sciences, 52200 Ordu-Turkey, deryabostanci@gmail.com

${ }^{3}$ Ondokuz Mayıs University, Faculty of Arts and Sciences, 55139 Samsun-Turkey, nazmipolat58@yahoo.com
}

${ }^{1}$ https://orcid.org/0000-0003-0017-3502 ${ }^{2}$ https://orcid.org/0000-0003-3052-9805 ${ }^{3}$ https://orcid.org/0000-0001-9785-9927 


\section{Introduction}

Turkey freshwater fish fauna has a rich biodiversity, including many endemic, native, and nonnative species (Çiçek et al., 2018). The geographical structure of Turkey is one of the most important factors in this diversity. There are quite a number of lakes, ponds, streams and rivers suitable for fish species in the Ordu province and there are more than 78 lotic and 8 lentic waters within the province borders (Bahtiyar Karadeniz and Sar1, 2018). There are many studies conducted on these freshwater resources in the Ordu. For instance, Melet River (Turan et al., 2008), Turnasuyu Stream (Bostanc1 et al., 2015), Curi River (Bostanc1 et al., 2016a), Yalıköy Stream (Bostanc1 et al., 2016b), Elekçi River (Yılmaz 2016; Saygun, 2021a), Ilıca River (Saygun et al., 2017), and Bolaman Stream (Saygun, 2021b).

The Nemacheilid family has 47 genera and about 696 species all over the world (Froese and Pauly, 2020). This family is represented in 49 species belonging to six genera such as Turcinoemacheilus, Paracobitis, Seminemacheilus, Barbatula, Schistura, and Oxynoemacheilus in Turkish waters. (Kaya et al., 2016; Çiçek et al., 2018; Turan et al., 2019). Oxynoemacheilus is the most common species in six genera of the Nemacheilidae family from Turkey, and this genus is represented by 41 species (Çiçek et al., 2019).

Angora loach, Oxynoemacheilus angorae (Steindachner, 1897) inhabits different habitats such as drainage basin, streams and muddy lakes in Iran, Israel, Jordan, Lebanon, Syria, and Turkey (Froese and Pauly, 2020). Its terra typica is Ankara (Turkey) (Saylar et al., 2020). The conservation status of $O$. angorae was classified as Least Concern (LC) according to the IUCN Red List Criteria (Freyhof, 2014). O. angorae individuals feed on benthic invertebrates and spawn the first time commonly at one year (Freyhof, 2014).

\section{Materials and Methods}

This study was conducted in the Meandering Streams at Perşembe Plateau, Aybast1-Ordu, Turkey (Middle Black Sea Region) at 40³8'14.5"N-37¹6'35.8"E coordinates (Figure 1). Fish samples were caught using the electrofishing gear at several sampling sites in the Meandering Streams, Aybast1-Ordu, Turkey (Figure 1).

Collected fish samples were fixed in 5\% formaldehyde solution and then transferred to the Hydrobiology laboratory at Ordu University for morphological investigation. The samples were identified based on Çiçek et al. (2019) and Froese and Pauly (2020). Meristic counts such as Dorsal fin rays (D), Anal fin rays (A), Pectoral fin rays (P), and Ventral fin rays (V) were performed for each sample. Linea lateral scales were counted on the left side of the fish samples. Body weight (nearest \pm 
$0.1 \mathrm{~g}$ ) of the samples were recorded, and the total length, fork length, and standard length (nearest \pm $0.1 \mathrm{~cm}$ ) were measured for each $O$. angorae sample. The smallest and largest samples were photographed.

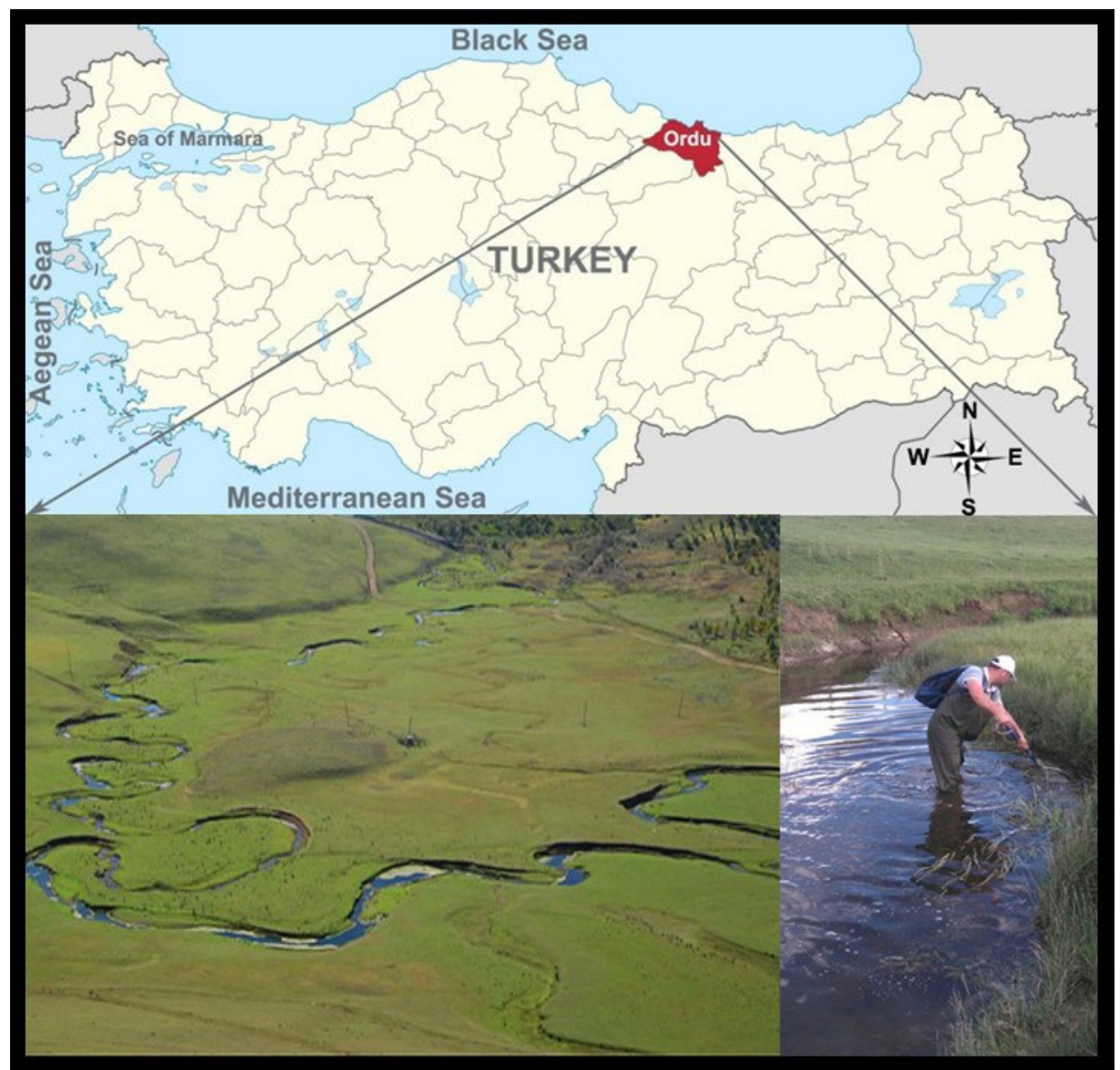

Figure 1. Sampling area.

\section{Findings and Discussion}

Ordu is one of the provinces of Turkey with high inland water potential, located in the Middle Black Sea Region. Although there are several studies on the freshwater fish fauna of Ordu (Turan et al., 2008; Dönel, 2012; Bostanc1 et al., 2015; 2016a,b, 2017; Y1lmaz, 2016; Saygun et., 2017; Saygun $2021 \mathrm{a}, \mathrm{b}$ ), there is no report on the presence of $O$. angorae in the fish fauna of Ordu. In the current study, a total of 15 O. angorae specimens were caught and the species is a new record for freshwater fish fauna of Ordu-Turkey (Middle Black Sea Region). The smallest and largest samples were present in Figure 2. Body weight of the fish samples is ranged from 1.5 to $4.6 \mathrm{~g}$. Standard length, fork length, and total length of all specimens are ranged from 4.6 to $6.8 \mathrm{~cm}$, from 5.3 to $7.7 \mathrm{~cm}$, from 5.5 to 8.0 $\mathrm{cm}$, respectively. Meristic characteristics of the samples were as D III/7-8, V II/6-7, A III/5, P I/9-10. As a result of the field studies we carried out in the Perşembe Plateau Meandering Streams (Ordu- 
Turkey), O. angorae in the inland water fish fauna of the Ordu is reported for the first time. Besides, metric and meristic data for this population of this species are presented for the first time.

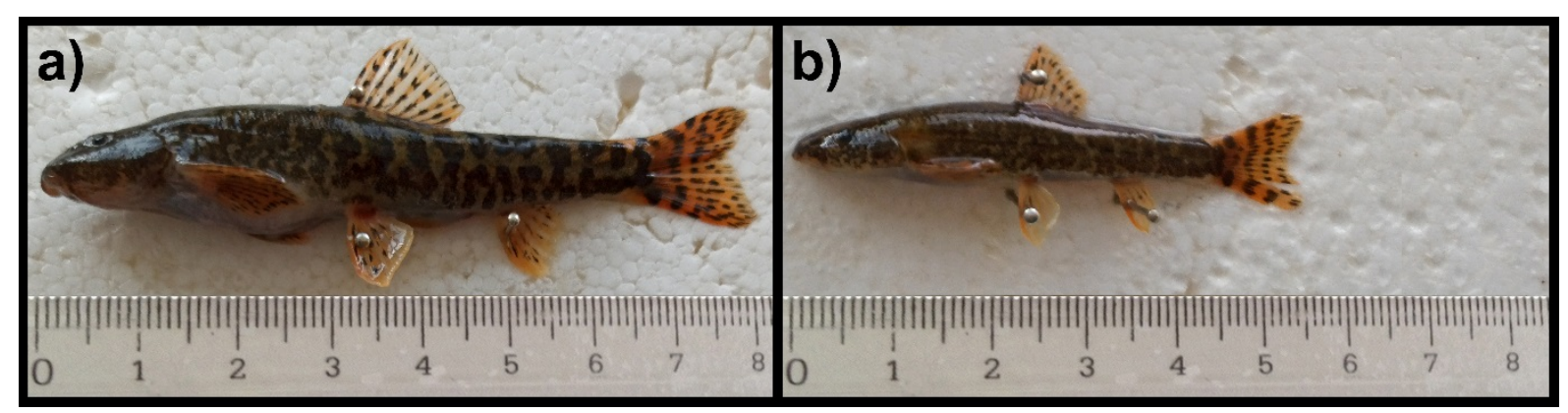

Figure 2. Largest (a) and smallest (b) $O$. angorae samples were captured from Perşembe Plateau Meandering Streams in the Ordu-Turkey.

When the meristic characteristics of $O$. angorae individuals in the literature were examined, it was found that there were slight differences in some meristic characters, although they were generally compatible with the data obtained in the current study (Table 1). These differences are estimated to be caused by the physicochemical characteristics of the sampling sites and some minor genetic differences of the individuals living in the relevant habitats.

Table 1. Meristic characters of Oxynoemacheilus angorae in different inland waters of Turkey.

\begin{tabular}{lccccccc}
\hline & This Study & $\begin{array}{c}\text { Polat and } \\
\text { Uğurlu 2007 }\end{array}$ & $\begin{array}{c}\text { Çoban et } \\
\text { al. 2013 }\end{array}$ & $\begin{array}{c}\text { Yildırım et } \\
\text { al. 2015 }\end{array}$ & $\begin{array}{c}\text { Koyun et } \\
\text { al. 2018 }\end{array}$ & $\begin{array}{c}\text { Saylar et } \\
\text { al. 2018 }\end{array}$ & $\begin{array}{c}\text { Çiçek et } \\
\text { al. 2019 }\end{array}$ \\
\hline Habitats & $\begin{array}{c}\text { Perşembe Plateau } \\
\text { Meandering }\end{array}$ & $\begin{array}{c}\text { Samsun inland } \\
\text { waters }\end{array}$ & $\begin{array}{c}\text { Uzunçaylr } \\
\text { Dam Lake }\end{array}$ & $\begin{array}{c}\text { Keban } \\
\text { Dam Lake }\end{array}$ & $\begin{array}{c}\text { Göynük } \\
\text { Stream }\end{array}$ & $\begin{array}{c}\text { Asartepe } \\
\text { Dam Lake }\end{array}$ & $\begin{array}{c}\text { Lake } \\
\text { Hazar }\end{array}$ \\
\hline $\mathrm{D}$ & III / 7-8 & III / 7-8 & II / 8 & II-III/ 7-8 & II / 8 & III / 7-8 & III / 7-8 \\
V & II / 6-7 & II / 6-8 & I / 6 & I / 6-7 & I / 7 & I / 7 & II / 6-7 \\
A & III / 5 & III / 5 & II / 5 & II / 5 & II / 5 & III / 5 & III / 5 \\
P & I / 9-10 & I / 9-11 & II / 5 & I / 9-10 & I / 9-10 & I / 9-10 & I / 9-11 \\
\hline
\end{tabular}

*D:Dorsal fin rays; V:Ventral fin rays; A:Anal fin rays; P:Pektoral fin rays

The Angora loach was reported in many Turkish inland waters such as Özkan et al. (2009) in the Kars river (Kars), Çoban et al. (2013) in the Uzunçayır Dam Lake (Tunceli), Gaygusuz et al. (2013) in the Balıklı Stream (Muğla), Erk'akan et al. (2014) in the Söğütözü Creek (Ankara), Yıldırım et al. (2015) in the Keban Dam Lake (Elazığg), Birecikligil et al. (2016) in the Kizılırmak River Basin (Nevşehir), Korkmaz and Zencirtanır (2016) in the Kirmir Stream (Sakarya), Yazıcıoğlu and Yazıcı (2016) in the Kılıçözü Stream (Kırşehir), Sağlam et al. (2017) in the Lake Hazar (Elazığ), Saylar et al. (2018) in the Asartepe Dam Lake, Çiçek et al. (2019) in the Çubuk Stream (Sakarya), and Turan et al. (2019) in the Black Sea basin (Turkey). 
In the current study, meristic characteristics of O. angorae were determined as D III/7-8, V II/67, A III/5, and P I/9-10 for Perşembe Plateau Meandering Streams population. Although these meristic characters are inappropriate intervals at the point of determining the species and show consistency in general when compared with the populations in other regions, it was determined that these meristic characters show some slight differences in the populations (Polat and Uğurlu, 2007; Çoban et al., 2013; Yıldırım et al., 2015; Koyun et al., 2018; Saylar et al., 2018; Çiçek et al., 2019). For instance, the number of anal fin rays was reported as A III/5 for Samsun inland waters, Asartepe Dam Lake, and Lake Hazar populations and it was A II/5 for Uzunçayır Dam Lake, Keban Dam Lake, and Göynük Stream populations. Similarly, the number of pectoral and ventral fin rays varies between populations in different ecosystems of the species (Table 1). When the literature is examined, the lowest value in the number of pectoral fin rays, which is one of the meristic characteristics, was reported in the Uzunçayır Dam Lake population (Çoban et al., 2013). Therefore, it should not be forgotten that ecosystem differences can affect both metric and meristic characteristics of fish species. More than one source and methodology should be used together, especially when making species discrimination and identification.

Relevant studies in the literature with this fish species examined in detail, it has been reported that the presence in different regions of Turkey, however, there is no information on the presence of the Ordu inland waters before. Therefore, this is the first record of O. angorae in the Ordu inland waters of the Middle Black Sea Region. Perşembe Plateau was declared a Tourism Center in 1991 with the decision of the Council of Ministers in Turkey. There are six meandering streams in the Perşembe Plateau at an altitude of 1500 meters, and they are a potential candidate for UNESCO World Cultural Heritage (Bahtiyar Karadeniz and Sarı, 2018; URL-1).

\section{Conclusions and Recommendations}

In the current study, the fact that $O$. angorae has been reported only in the meandering streams from the inland waters of Ordu proves that the meandering streams are suitable for the life of this species and that this is the only distribution area of the species in the Ordu. For this reason, O. angorae and the meandering streams are very important for fish biodiversity in the Ordu. However, animal husbandry and tourism activities are carried out in suitable seasons in the Perşembe Plateau within the borders of Ordu province. It is necessary to preserve the naturalness of the meandering streams, which is an important center of attraction for Ordu, and to determine whether the fish species living in these meandering streams are affected by these activities and to monitor them. 


\section{Authors' Contributions}

SY, DB, and NP performed data collection and analysis. SY and DB designed the research and writing manuscript. All authors discussed the results and contributed to the final manuscript.

\section{Statement of Conflicts of Interest}

There is no conflict of interest between the authors.

\section{Statement of Research and Publication Ethics}

The authors declare that this study complies with Research and Publication Ethics.

\section{References}

Bahtiyar Karadeniz, C., and Sari, S. (2018). Evaluation of tourism potential based on natural resources of Ordu province. The Journal of International Social Research, 61(11),741-759. DOI:10.17719/jisr.2018.2968

Birecikligil, S. S., Çiçek, E., Öztürk, S., Seçer, B., and Celepoğlu, Y. (2016). Length-length, length-weight relationship and condition factor of fishes in Nevşehir Province, Kızılırmak River Basin (Turkey). Acta Biologica Turcica, 29(3), 72-77.

Bostanc1, D., İskender, R., Helli, S., and Polat, N. (2015). The determination of fish fauna of Turnasuyu Stream (Ordu). Ordu Üniversitesi Bilim ve Teknoloji Dergisi, 5(2), 1-9.

Bostanc1, D., İskender, R., Helli, S., and Polat, N. (2016a). The fish of the Curi Stream (Ordu) and invasive fish species Carassius gibelio (Bloch, 1782). Journal of Aquaculture Engineering and Fisheries Research, 2(1), 11-19. DOI:10.3153/JAEFR16002

Bostanc1, D., Darçın, M., and Helli, S. (2016b). A study on the investigation of fish fauna of Yalıköy Stream (Ordu). Ordu Üniversitesi Bilim ve Teknoloji Dergisi, 6(2), 146-157.

Bostanc1, D., Yedier, S., Kontaş, S., Kurucu, G., and Polat, N. (2017). Length-weight, length-length relationships and condition factors of some fish species in Yalıköy Stream (Ordu-Turkey). Aquaculture Studies, 17(4), 375-383. DOI:10.17693/yunusae.v17i31121.339920

Çiçek, E., Eagderi, S., and Sungur, S. (2019). Oxynoemacheilus phoxinoides (Erk'akan, Nalbant \& Özeren, 2007): a junior synonym of Oxynoemacheilus angorae (Steindachner, 1897). FishTaxa, 4(1), 13-17.

Çiçek, E., Fricke, R., Sungur, S. \& Eagderi, E. (2018). Endemic freshwater fishes of Turkey. FishTaxa, 3(4), $1-39$.

Çoban, M. Z., Gündüz, F., Yüksel, F., Demirol, F., Yıldırım, T., and Kurtoğlu, M. (2013). Fish fauna of Uzunçayır Dam Lake (Tunceli). Aquaculture Studies, 13(2), 35-44. DOI:10.17693/yunusae.v2013i21905.235421

Dönel, E. K. (2012). Gaga Gölü (Ordu-Türkiye) balık faunasının belirlenmesi. Yüksek Lisans Tezi, Ordu Üniversitesi, Fen Bilimleri Enstitüsü, Ordu.

Erk'akan, F., Innal, D., and Özdemir, F. (2014). Length-weight relationships for some endemic stone and spine loach species in Anatolia. Journal of Applied Ichthyology, 30(1), 244-245. DOI:10.1111/jai.12260

Freyhof, J. (2014). Oxynoemacheilus angorae. The IUCN Red List of Threatened Species 2014: e.T14493A19849461.

Froese, R., and Pauly, D. (2020). Fishbase, Species list: Oxynoemacheilus angorae, [Date Accessed: 2021 Jan 5]. Available from https://www.fishbase.se/summary/25993

Gaygusuz, Ö., Aydın, H., Emiroğlu, Ö., Top, N., Dorak, Z., Gürsoy Gaygusuz, Ç., Başkurt, S., and Tarkan A. S. (2013). Length-weight relationships of freshwater fishes from the western part of Anatolia, Turkey. Journal of Applied Ichthyology, 29(1), 285-287. DOI:10.1111/jai.12015 
Kaya, C., Turan, D., and Ünlü, E. (2016). The latest status and distribution of fishes in upper Tigris River and two new records for Turkish freshwaters. Turkish Journal of Fisheries and Aquatic Sciences, 16, 545562. DOI:10.4194/1303-2712-v16 307

Korkmaz, A., and Zencirtanır, Ö. (2016). Fish species biodiversity in Kirmir Stream of Sakarya River, Turkey. Journal of Limnology and Freshwater Fisheries Research, 2(3), 145-151. DOI:10.17216/limnofish.267103

Koyun, M., Gül, B., and Korkut, N. (2018). The fish fauna of Göynük Stream (Bingöl). Commagene Journal of Biology, 2(1), 39-47. DOI:10.31594/commagene.403367

Özkan, O., Gül, S., Keleş, O., Aksu, P., Kaya, T. Ö., and Nur, G. (2009). The investigation of the mutagenic activity of Kars River sediments on Orthrias angorae (Steindahner, 1897). Kafkas Universitesi Veteriner Fakültesi Dergisi, 15(1), 35-40.

Polat, N., and Uğurlu, S. (2007). Samsun ili tatlı su balık faunası. Ladik Doğayı ve Çevreyi Koruma Derneği, Samsun, Türkiye.

Sağlam, N., Şen, B., Alnay, M., Dartay, M., Özbay, Ö., Tuğyan, H. P., Türker, A., Ateşşahin, T., and Sapmaz, M. (2017). Fish and fisheries in Lake Hazar. 2nd Workshop on National Environment and Water Management, 11-12 May 2017. Elazığ, Turkey.

Saygun, S., Turan, D., Saygun, F., Kabaday1, M., Yılmaz, H., and Ataç, T. (2017). Contributions to fish fauna of the Ilica River Fatsa/Turkey. Biological Diversity and Conservation, 10(2), 141-154.

Saygun, S. (2021a). The new record native and non-native species for the ichthyofauna of Elekçi River (Turkey). Biological Diversity and Conservation, 14(1), 13-23. DOI:10.46309/biodicon.2021.798644

Saygun, S. (2021b). The fishes of the Bolaman Stream, Northern Turkey. Aquatic Research, 4(1), 38-54. DOI:10.3153/AR21004

Saylar, Ö., Gül, G., Y1lmaz, M., and Gül, A. (2018). Fish fauna in Asartepe Dam Lake (Ankara). Journal of Limnology and Freshwater Fisheries Research, 4, 90-97. DOI:10.17216/LimnoFish.426094

Saylar, Ö., Ata, B., and Firidin, B. (2020). Some population characteristics of Oxynoemachellus angorae (Steindachner, 1897) living in Ankara Asartepe Dam Lake. Journal of Anatolian Environmental and Animal Sciences, 5(4), 711-716. DOI:10.35229/jaes.824177

Turan, D., Kaya, C., Kalaycı, G., Bayçelebi, E., and Aksu, İ. (2019). Oxynoemacheilus cemali, a new species of stone loach (Teleostei: Nemacheilidae) from the Çoruh River drainage, Turkey. Journal of Fish Biology, 94, 458-468. DOI:10.1111/jfb.13909

Turan, D., Taş, B., Çelik, M., and Yılmaz, Z. (2008). Fish fauna of the lower part of River Melet (Ordu, Turkey). Journal of FisheriesSciences.com, 2(5), 698-703. DOI:10.3153/jfscom.2008037

URL-1. Perşembe Yaylası-Aybast//Ordu; [Date Accessed 2021 Jan 5]. Available from https://ordu.ktb.gov.tr/TR-130730/persembe-yaylasi-aybastiordu.html

Yazıcıoğlu, O., and Yazıc1, R. (2016). The length-weight, length-length relationship and condition factor of Angora loach, Oxynoemacheilus angorae (Steindachner, 1897) inhabiting Kılıçözü Stream in Kizilırmak River Basin (Central AnatoliaTurkey). Turkish Journal of Agriculture-Food Science and Technology, 4(12), 1165-1168. DOI:10.24925/turjaf.v4i12.1165-1168.973

Yıldırım, T., Şen, D., Eroğlu, M., Çoban, M. Z., Demirol, F., Gündüz, F., Arca, S., Demir, T., Gürçay, S., Uslu, A. A., and Canpolat, İ. (2015). The fish fauna of Keban Dam Lake, Elazı ğ, Turkey. Firat University Journal of Science, 27(1), 57-69.

Yilmaz, E. (2016). Fish fauna of the Elekçi River (Fatsa/Ordu). SDU Journal of Science (E-Journal), 11(2), $1-12$. 